Available online at website :

http:/ / e-journal.adpgmiindonesia.com/index.php/jmie

JMIE: Journal of Madrasah Ibtidaiyah Education, 5(1), 2021, 110-123

\title{
GAME METHOD WITH MEDIA CHART TABLE FROM USED ITEMS TO INCREASE MOTIVATION, INTEREST, AND RESULTS
}

\author{
Wahyu Bagja Sulfemi' ${ }^{1}$, Tia Fajartriani ${ }^{2}$, Trissia Handayani ${ }^{3)}$ \\ Sekolah Tinggi Keguruan dan Ilmu Pendidika (STKIP) Muhammadiyah Bogor ${ }^{1,2)}$, Sekolah \\ Dasar Islam Terpadu (SDIT) Al-Hamidiyah ${ }^{3)}$ \\ Email:wahyubagja@gmail.com ${ }^{1)}$,fajartriani@gmail.com²),t3shandayai@gmail.com ${ }^{3)}$
}

\begin{abstract}
This class action research is a descriptive quantitative study conducted in class III Abu Bakar Ash-Shiddiq SDIT Al-Hamidiyah, amounting to 28 people consisting of 14 male students and 14 female students. This study aims to improve the learning outcomes of grade IV students at SDIT Al-Hamidiyah in Social Sciences subjects about the Nature Appearance and SocioCultural Diversity using the game method through the media chart tables of used goods. This research was conducted in two cycles. Data collected in this study are quantitative data in the form of student learning outcomes. In pre-cycle learning, 6 students $(21 \%)$ and not yet 22 people $(79 \%)$ had completed students. In cycle 1 learning, 11 students (39\%) completed and 17 students $(61 \%)$ were incomplete. Cycle 2 was completed 27 people $(96 \%)$ and those who were not yet 1 person (4\%). The results of the analysis of this study indicate an increase in student learning outcomes starting from cycle $139 \%$ to $96 \%$ in cycle 2 . The results of the study can be concluded that the use of the game method with a chart table of used goods can increase motivation, interest, and social science education outcomes.
\end{abstract}

Keywords: game methods, and chart media, social sciences

Pengutipan: Wahyu Bagja Sufemi, dkk. (2021). Game Method with Media Chart Table from Used Items to Increase Motivation, Interest, and Results. JMIE: Journal of Madrasah Ibtidaiyah Education, 5(1), 2021, 110-123. jmie.v5i1.225.

Permalink/DOI: http://dx.doi.org/10.32934/jmie.v5i1.225 



\section{INTRODUCTION}

Education is the basis for the intellectual life of the nation under the objectives of the Republic of Indonesia. In education in primary schools, the aim is to provide basic intellectual abilities in reading and writing, as well as various other basic skills processes that enable the development of learners' abilities to be more optima (Yuliana et al., 2015). Students become estuaries in educational and learning activities because students will develop themselves as humans who have the potential to be fostered and mentored by teacher intermediaries (Sulfemi, 2020). Students in elementary schools are students who have characteristics that are not yet mature and have basic traits that are developing in an integrated manner that has biological, spiritual, social, intelligence, emotional, speech, limbs needs to work according to biological and social backgrounds and differences between individuals (Sediasih, 2017). In the implementation of learning in elementary schools, each subject is taught under their respective goals in preparing students. Social sciences is a field of study that has a scope of knowledge covering the symptoms and problems of human life in society (Arsyad et al., 2020). Each field of study listed in the school curriculum has goals that must be achieved in the implementation of the Teaching and Learning Process. One of the objectives of studying Social Sciences at the elementary school level is to equip students with useful social knowledge in their future lives in society (Sulfemi \& Mayasari, 2019). The learning process emphasizes the natural environment around and the community. Students will know the conditions and situations in the immediate environment after learning Social Sciences (Azizah, 2016).

To achieve these learning objectives, teachers should have the ability to manage the learning process properly like a chef who prepares delicious dishes requires skills to manage to learn effectively, efficiently, and fun (Sutedi, 2016). For this reason, appropriate and fun models, methods, and media are needed in learning. Sometimes teachers encounter several obstacles and obstacles in the activity of learning and teaching. Students assume that learning social sciencesis considered difficult and unpleasant so it is less active and not focused when learning. Based on observations of students' learning outcomes about Natural Appearance and Socio-Cultural Diversity, in class IV of the Al-Hamidiyah Integrated Ibtidaiyah Elementary School, it was found that student learning outcomes were still low. Based on the results of the worksheets students found $79 \%, 22$ of 28 students the value is still below the Minimum Completion Criteria set is 75 . While students who obtain learning outcomes above the Minimum Mastery Criteria as much as $21 \%$ namely 6 people.

It turns out that the low learning outcomes of Social Sciences lessons are also in accordance with research conducted by Windiyani et al., (2018) out of 30 students only 10 students or $33.3 \%$ were stated to have achieved the Minimum Mastery Criteria. Wartik, (2017) that the value obtained by students is only 53.67 of the Minimum 70 completeness Criteria specified. Subsequent research conducted by Putri, (2018), based on the results of preliminary research on third-grade students in Primary Schools in Bagan Jaya, was still low, out of 28 students there were 18 students who had not yet reached the Minimum Mastery Criteria. A study by Damanhuri et al., (2016) who conducted research in SDN Anyar 2, the observer found that student learning outcomes were still below average, material in learning Social Sciences was often presented abstractly, and Social Science Learning was less meaningful. 
The low learning outcomes several factors are causing it, namely: 1) The method used is not interesting, namely the lecture method, 2) The media used is less varied, 3) The learning conditions take place during the day, and 4) Lack of enthusiasm during the learning process. It must be realized that the low score is mainly due to the teacher and student factors. The teacher as an important component in the teaching and learning process has a very strategic role in the effort to establish quality human resources with the task of implementing learning and evaluating learning. Even teachers are expected to modify the design and implementation of teaching, play an active role and position as a professional staff, by the demands of a growing community to improve student learning outcomes by expectations (Sulfemi \& Minati, 2018), (Sukmanasa et al., (2017). Learning in the process will involve various components, including: (1) objectives, (2) learning subjects, (3) subject matter, (4) learning strategies, (5) learning media, and (6) support. The main component in the learning system is the subject of learning because it acts as a subject as well as an object (Anitah, 2014: 5.4). The subject of learning, in this case, is the students. Students are members of the community who are trying to develop their potential through a learning process that is available in the formal and nonformal education channels at the level of primary and secondary education. In the learning process, students cannot learn on their own without the role of the teacher (Sulfemi \& Yuliana, 2019).

In learning, the media can reduce the lack of teachers in explaining the subject matter in class. However, it should be remembered that the role of the media will not be seen if its use is not in line with the essence of the teaching objectives that have been formulated. The learning media used by the teacher in the learning process has a role in explaining abstract things and showing hidden things. The lack of clarity or complexity of the learning material can be helped by presenting the media as an intermediary. The presence of instructional media means the position of the teacher is no longer the sole source of learning, but as a facilitator and motivator and it is hoped that learning is centered on students.

Lack of motivation, interest, and learning outcomes, further studies are needed on improving the learning of Social Sciences. For this reason, the author tries to make improvements by using the game method with a media chart table of used goods. The use of methods and media are expected in teacher learning to make students not only have motivation, interest and make it easier for students to learn the material provided, but students can also provide and teach fun by utilizing the surrounding environment. So that in this learning the teacher only acts as a mediator, facilitator, and motivator.

\section{METHODS}

This research uses the action research method. The emphasis is focused on collecting information and data from four sources, namely, (1) collaborators, (2) Homeroom, (3) learning material from the curriculum and student handbooks, (3) the course of the learning process itself, and (4) several students in the class, both done through interviews and observations (Sulfemi \& Setianingsih, 2018). 
The research subjects were grade IV students of SDIT Al-Hamidiyah consisting of 28 students, namely 14 men and 14 women. SDIT Al-Hamidiyah is located at Jalan Raya Depok Sawangan KM 2 No 12, Kelurahan Rangkap Jaya, Pancoranmas District, Depok City. This school is a private school under the Al-Hamidiyah Islamic Foundation which has No. NPSN 20247304. The subject chosen is Social Sciences with the theme 'Important Events in the Family.'

The CAR model used is the Elliot model which requires that action research activities be carried out through the stages of research namely general planning, implementation, monitoring of implementation and effects, failure explanation, and redesign. According to Miaz, (2015): 2; Sulfemi \& Kamalia, (2020). There are 4 stages in this study, namely: 1) Arranging the design of action (planning), 2) Implementation of the action (acting), 3) Observation (observing), and 4) Reflection (reflecting). Data analysis in this action research was carried out in a descriptive qualitative manner, in the sense that the data obtained by using a learning model of a game method with a media chart of used goods were analyzed descriptively. Qualitative analysis is carried out to systematically search for and compile data obtained from interviews, field notes, and documentation, by organizing data into categories, describing them in units (themes), synthesizing, compiling into patterns, selecting important meanings and make conclusions so that they are easily understood by themselves and others. (Heryadi et al., 2020).

There are four instruments used in this study, in the form of 1) Learning outcomes test. This test quiz is given at the end of learning, which serves as a measure of the success of the delivery of material. While the learning achievement test is given at the end of the cycle I and cycle II, it functions to find out the students' ability in solving social problems while at the same time knowing the level of student learning outcomes, 2) Observation guidelines. To observe things that occur during the process of implementing learning takes place using the observation deck which consists of observation sheets for teacher, student, and material activities, 3) Field Notes, namely written notes about what was heard, seen, experienced, and thought by researchers to collect data and reflect on data in qualitative research and, 4) Documentation, this instrument is used as a data reinforcement obtained at the same time as a real picture of the implementation of research. This document is a collection of photos of learning activities (Daryanto, 2014: 6).

The results of data from pre-cycle, cycle I and cycle II were obtained from written tests. In the pre-cycle questions given in the form of 10 multiple choice questions and 5 essay questions, the first cycle of questions in the form of multiple-choice as many as 10 multiple choices and 5 essay questions, and in the second cycle the questions are given a combination of 10 multiple choice questions and essay questions. To measure the success of the learning model used, this study uses the following indicators: 1) The method of the game method with a chart of used goods is said to be successful in the learning process if the teacher's activities are effective in providing guidance to explore students' ideas, compiling hypotheses, testing hypotheses by making observations, conducting group discussions, assigning students to make group work in the form of reports and conclusions with the criteria of achieving success $\geq$ $80 \%$. 2) The model is considered successful if the learning process shows student activities, 
which include: students ask questions according to the problem, students can answer the teacher's questions verbally, active in group discussions, by achieving success $\geq 80 \%$. 3) Student learning outcomes are considered to meet minimum completeness criteria if the evaluation results obtain a value of $\geq 75$. To achieve classical completeness will be achieved if all students in the class or average class reach $80 \%$.

Data collected on each research activity from the implementation of the research cycle were analyzed descriptively using percentage techniques to see trends occurring in social studies subject learning activities. To assess repetitions or formative tests the sum of the values obtained by students was further divided by the number of participants students in the class so that the average formative test can be formulated $\bar{X}=\frac{\sum X}{\sum N}$, Range of data with the formula $\mathrm{R}=\mathrm{X}_{\mathrm{t}}-\mathrm{X}_{\mathrm{r}}$, Number of Classes $(\mathrm{BK})$ with the formula $\mathrm{K}=1+3,3 \log \mathrm{n}$, Interval Length $(\mathrm{P})$ with formula $\mathrm{P}=\frac{\mathrm{R}}{\mathrm{BK}}$, Frequency percentage with formula $\mathrm{P}=\frac{f}{N} \times 100 \%$. To calculate the percentage of mastery learning used the following formula: $\mathrm{P}=$ $\frac{\sum \text { complete student learning }}{\sum \text { whole student } n} \times 100 \%$ (Sulfemi et al., 2020).

The results of the analysis are then compared with the data obtained in cycle 1 and cycle 2. Based on this analysis it can be seen: have the student learning outcomes improved? What is the percentage increase? Indicators to measure the increase in student learning outcomes are increasing student learning outcomes individually or classically. For this reason, the authors add up the overall value of the students. From the total score, the writer looks for the grade average. The average value of the class is obtained from the total value of the students divided by determining the range, namely the largest data acquisition of students minus the smallest data. If the range is known, then an evaluation of the results of each learning interval can be made starting from pre-cycle, cycle 1 and cycle 2.

\section{RESULTS AND DISCUSSION}

In making making improvements to learning began to be carried out steps in the following order: First, planning. In this planning several are carried out, namely: a). Develop learning plans, b) Determine learning indicators and objectives, c) Determine learning steps, d) Determine the material to be delivered in this pre-cycle is about the Appearance of Nature and Socio-Cultural Diversity, e) Determine learning methods, Determine learning tools and media, f) Prepare students' worksheets and arrange learning evaluations. Second, action. The actions taken are as follows: a) Guided by the student's teacher to mention the opposite of the existing word, b) The teacher explains about the Appearance of Nature and Socio-Cultural Diversity, and c) The teacher gives an evaluation sheet. Third, data analysis. The author also made several instruments used by the writer as a benchmark in improving the learning process. These instruments are: a) Observation Instrument to find out the learning outcomes of students, b) Student observation instruments that can answer and cannot answer questions from the teacher, and c) Evaluation sheet for each cycle by writing a class average. 
In the implementation of Pre-cycle learning activities that begin with the introduction a,) conditions the students to be ready to follow the learning process, b) invites students to read prayers, c) checks the presence of students. d) Motivating students to concentrate and be active when exploring, e) ask questions related to the material, and f) explain the learning objectives. At the core activities that use the lecture method as conveyed by Sulfemi, (2019), the following actions are taken: a) Explores the understanding of Natural Appearance and Socio-Cultural Diversity, b) Students pay attention to the teacher's explanation of the material and answer teacher questions, c) Participants students are instructed to do assignments from worksheets, d) Students work on worksheets about Natural Appearance and Socio-Cultural Diversity, e) Students and teachers conduct question and answer questions relating to material to correct misunderstandings, f) Students are given reinforcement of material and motivation.

The closing activities carried out the following actions: 1) allow students to ask questions that have not been understood, 2) Students are guided to conclude the material, 3) Students are given the task of evaluation, 4) Evaluation of evaluation results, 5) Giving feedback, and 6) End the learning activities by saying greetings.In the pre-cycle activities, a total score of 1660 was obtained, with a breakdown of the highest score of 80 and the lowest value of 40. The average grade of 59 students who completed the learning process was only 6 people, and 22 students from a total of 28 students were not yet finished. With the details of 14 male students and 14 female students. Mastery learning obtained by $21 \%$ of students reached KKM and $79 \%$ The results of the calculation of the interval value of the Social Sciences learning outcomes in Pre-cycle obtained 40 data ranges, many 5.78 class intervals were rounded to 6 , and the length of the interval classes obtained 6.667 rounded up to 7.

The observations of teachers during pre-cycle learning who have the courage and can answer the teacher's questions correctly only reached 6 students out of 28 students or $21 \%$. While those who have not answered correctly are 21 children out of 28 students or $79 \%$. To see more clearly the following table presents learning outcomes and teacher observations on Pre-cycle learning. Based on data from interim grade interval results obtained by students who are in the range of values 73-80 there are 6 students, the range of values 65-72 there are 2 students, the range of values 57-64 there are 11 students, the range of values 49-56 there were 11 students, 41-48 there were none, and the range of values of 33-40 there were 3 students.

Based on the observations made, several things were found to be a problem, namely: most students could not answer the questions correctly so the results obtained were not by the expected targets as follows: 1) Students did not understand the material presented, 2) Learning methods not quite right, 3) The learning media used are not interesting enough, and 4) The teacher is less motivating students to be active in learning activities.

The low level of learning in the pre-cycle then the next lesson is learned in cycle 1 . In learning activities begin with planning as in pre-cycle 1 only in this activity coupled with preparing learning media in the form of puzzle applications about antonyms and evaluation sheets in the form of 10 question numbers.

At the preliminary stage, it is almost the same as the pre-cycle. For the Core activities at the exploration stage, the action is carried out by exploring the understanding of the 
Material of Natural Appearance and Socio-Cultural Diversity and the students pay attention to the material with audio-visual media and the participants answer the questions raised by the teacher. In the elaboration phase, the following activities were carried out: 1) Students were asked to puzzle about the Appearance of Nature and Socio-Cultural Diversity, 2) the students together with the teacher played a puzzle. The teacher mentions words that have the potential to have the material Natural Appearance and Socio-Cultural Diversity while the students mention the material Natural Appearance and Socio-Cultural Diversity of these words simultaneously, 3) Students in pairs, are given the task to understand discourse then identify potential words that have Natural Appearance and Socio-Cultural Diversity regarding Natural Appearance and Socio-Cultural Diversity, 4) Each group writes the words along with Natural Appearance and Socio-Cultural Diversity on the worksheets that have been provided, 5) Discuss the results of joint discussions, with representatives of the group going forward class, 6) Students are given worksheets to work on, 7) Students who do not understand the tasks given are guided by the teacher, 8) Work on worksheets on Natural Appearance and SocioCultural Diversity. At the confirmation stage, the students and the teacher ask questions and answers related to the material to correct misunderstandings and students are given reinforcement of the material and motivation. The closing activity is almost the same as during the pre-cycle.

Learning Outcomes in the first cycle phase obtained an overall value of 2000 with the breakdown of the highest score of 90 and the lowest value of 50 . The average class result is 71. Students who complete are 11 people and 17 students out of the total number of students 28, participants there are 6 male students while 5 female students. This mastery learning if $39 \%$ is complete and $61 \%$ is incomplete. The results of the calculation of the interval value of the results of learning Social Sciences in Cycle 1 obtained range of data 40, many class intervals 5.78 rounded to 6 , and the length of the interval class obtained 6.667 rounded to 7 . The observations of teachers during Cycle 1 learning who had the courage and were able to answer the teacher's questions correctly reached 15 students out of 28 students or $54 \%$. While 13 children out of 28 students have not answered correctly or $46 \%$. To see more clearly the following table presents learning outcomes and teacher observations on learning Cycle 1. Based on the above calculation, the frequency distribution interval can be known the number of students who are in the range of values of 83-90 there are 7 students, range of values 75-82 there are 4 students, range of values 67-74 there are 6 students, range the range of values 5966 there are not 7 students, the range of values 51-58 there are no students, the range of values 43-50 there are 4 students.

After being observed during the implementation of learning by students according to the learning scenario. Peers observe and record the activities carried out by the teacher in the learning process using observation sheets that have been prepared. The following is the result of observations from the author and peers who will be a material for improvement in the next learning (cycle two), namely: 1) In providing material, there are still students who have not been focused when learning takes place, 2) The activeness of students has begun to be seen during the discussion. Even though it is still not much, 3) Group presentations cannot be done because time is mostly used to discipline students. So the teacher immediately gives an 
evaluation. Not achieving the value of participants in cycle 1 then the next step in learning Cycle 2. The planning stage is almost the same when pre-cycle and cycle 1 are only added. Students are asked to collect used bottles and learning media in the form of a chart of materials Natural Appearance and Socio-Cultural Diversity of used goods. Whereas for evaluation used 10 questions in the form of multiple-choice questions.

In the stages of the preliminary implementation of the exploration phase is almost the same as the pre-cycle and cycle 1. For the core activities of the Elaboration stage the following actions are carried out: 1) Students are divided into 7 groups. Each group consists of 4 people. By taking color. Each student who gets the same color of paper gathered in 1 group, 2) Each group is given a media chart table Appearance of Nature and Socio-Cultural Diversity on Nature Appearance and Socio-Cultural Diversity, 3) Students listen to the teacher's explanation of the procedure for playing media chart table, 4) Students are given worksheets, 5) Students play chart series 1, 2, 3 and 4,5) Students listen to the applause on the teacher and then turn in a clockwise direction, 6) Students write answers on the sheet work, 7) Students who do not understand the task given are guided by the teacher, 8) Representatives of each group present the results of the discussion, while other groups respond to it, 9) Groups with the best discussion results are given awards, and 10) Students work on worksheets about the Material Appearance of Nature and Socio-Cultural Diversity and write down the opposite words. For confirmation and closing activities almost the same at the time of the 1st cycle. Learning Outcomes in the second cycle stage obtained an overall value of 2620 with details of the highest value of 100 and the lowest value of 60 . The average grade of 94 results. The complete students numbered 27 people. This mastery learning if the percentage of $96 \%$ is complete and $4 \%$ is not complete. The results of the calculation of the interval value of Social Sciences learning outcomes in Cycle 2 obtained a range of data 40, many class intervals 5.78 rounded to 6 , and the length of the interval class obtained 6.667 rounded to 7 . Based on these data obtained intervals of the frequency distribution of students who are in the range of values: 93-100 there are 16 students, range values 85-92 there are 9 students, range values 7784 there are 1 student, range values 69-76 there are no students, 53-60 there is 1 student.

The observations of teachers during Cycle 2 learning who had the courage and were able to answer the teacher's questions correctly reached 27 students out of 28 students or $21 \%$. While those who have not answered correctly are 1 child out of 28 students or $4 \%$. The author and colleagues reflect on the improvement of learning. Several things are very influential on the application of the game method by using chart media from used goods, namely: 1) By using the game method and chart media, students get a new atmosphere so that learning becomes more enjoyable, 2) Students look more enthusiastic and avoid from boredom, 3) The increase in the class average results achieved by students was 94 . With the results that have reached this KKM, the writer does not need to continue to the next cycle. The following summarizes Student Learning Outcomes and Students' Learning Observation Results for each cycle presented in the following table and graph 
Table 1.Percentage of success of student learning outcomes

\begin{tabular}{|c|c|c|c|c|c|c|c|}
\hline \multirow{2}{*}{ No } & \multirow{2}{*}{ Criteria } & \multicolumn{2}{|c|}{ Pre-Cycle } & \multicolumn{2}{|c|}{ Cycle 1} & \multicolumn{2}{|c|}{ Cycle 2} \\
\hline & & Amount & $\%$ & Amount & $\%$ & Amount & $\%$ \\
\hline 1. & Complete & 6 & $6 \%$ & 11 & $39 \%$ & 27 & $96 \%$ \\
\hline 2. & Not Completed & 22 & $79 \%$ & 17 & $61 \%$ & 1 & $4 \%$ \\
\hline \multicolumn{2}{|c|}{ Average value of } & & & \multicolumn{2}{|c|}{59} & \multicolumn{2}{|c|}{71} \\
\hline
\end{tabular}

Table 2.Percentage of success of observations of student learning

\begin{tabular}{llcccccc}
\hline \multirow{2}{*}{ NO } & \multirow{2}{*}{ Criteria } & \multicolumn{2}{c}{ Pre-Cycle } & \multicolumn{2}{c}{ Cycle 1 } & \multicolumn{2}{c}{ Cycle 2 } \\
& & Amount & $\mathbf{\%}$ & Amount & $\%$ & Amount & $\%$ \\
\hline 1. & Can Answer & 6 & $6 \%$ & 15 & $54 \%$ & 27 & $96 \%$ \\
2. & Cannot Answer & 22 & $79 \%$ & 13 & $46 \%$ & 1 & $4 \%$ \\
& Amount & 28 & $100 \%$ & 28 & $100 \%$ & 28 & $100 \%$ \\
\hline
\end{tabular}

Based on the summary of Student Learning Outcomes and Students' Learning Observation results each cycle presented can be made as follows

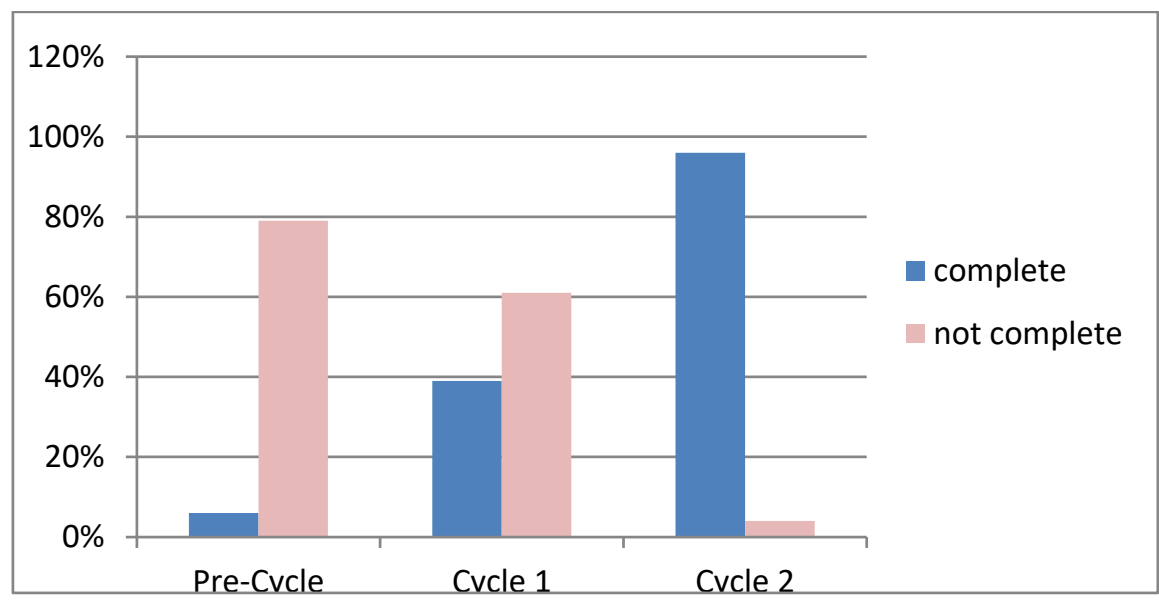

Graph 1. The Success of Student Learning Outcomes Each Cycle 


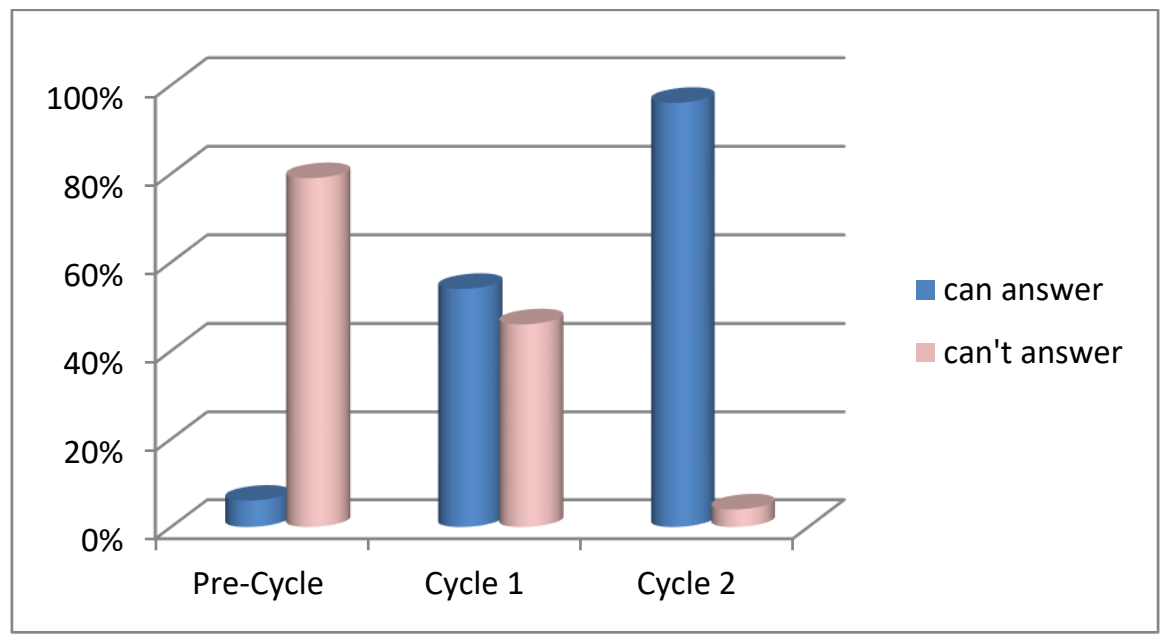

\section{Graph 2. The Success of Student Observation Learning Outcomes Every Cycle}

Based on the data obtained by the authors through observation with colleagues, starting from the stages of pre-cycle, cycle 1, cycle 2 in the Social Sciences lesson shows that there are changes and improvements in learning outcomes for the better. The use of the game method with the media chart of used goods in the material Material Natural Appearance and Socio-Cultural Diversity in class IV Integrated Ibtidaiyah Primary School Al-Hamidiyah Depok can help improve students' motivation, interest, and learning outcomes. This is caused by 1) The use of methods that are less precise and less attractive so that students get bored easily. 2) The use of the lecture method used by the teacher does not allow students to ask questions. 3) Students do not yet have a strong desire to learn, 3) During learning takes place the teacher lacks motivation for students, and 4) Less varied learning methods lead to a lack of classroom mastery. Based on the results of the study there was an increase in the percentage of learning evaluation results. This indicates that the use of the game method with the help of media charts of used goods that are applied in the study of Social Sciences can help students in understanding the material Natural Appearance and Socio-Cultural Diversity. Learners are also motivated in learning. Using the chart media from used goods can help the teacher in presenting the material. The teacher switches roles to become a facilitator who helps and makes it easy for students to learn.

The author's research results are in line with what was studied by Anggraini, (2018) and Aliputri, (2018) that the media of used goods or materials have advantages or positive aspects, namely in terms of economic prices that are cheap and easily available around us. Also, the use of used items as teaching aids has the benefit of increasing student activity, saving economical study time. Utilization of users can also reduce the pile of garbage in our environment. In this case, the use of used materials will increasingly make use of materials that are no longer used as useful items and can increase students' interest and creativity because used bottles are widely available among students. 
The use of the game method as presented, Nikmah et al., (2013) is a learning method where the material is delivered through a fun activity that can support the creation of instructional objectives both cognitive, affective and psychomotor aspects. Students can play while learning to obtain and find certain understandings and concepts. Through this method, students carry out activities (games) within the framework of the teaching and learning process, both individually and in groups, according to Mujinem \& Kawuryan, (2013) and Gunadi, (2012), the game method is assessed as a method of learning that is systematic, easy and enjoyable when applied to the child.

This game method with used goods media can be used as an alternative to creating fun learning activities, as well as triggering student motivation. So educators need to carry out fun learning activities so that students are motivated in learning. Apart from that, it can effectively change class dynamics. Usually, with students' games looking more relaxed, motivation also looks greater for learning and acting. This is as stated by Ginnis, (2008: 214) with this role-playing method the game can be useful as follows: 1) The creation of a more flexible working relationship between students and teachers, 2) Interlocking interactive between teacher and students, 3) Not much energy from the teacher, 4) Students can be more focused, and 5) Can train and provide students' thinking skills without having to work hard.

Thus, classroom action research using the game method with table chart media of used goods can provide the following benefits: 1) To solve real problems that occur in the classroom that are experienced directly in the interaction between students and teachers, can increase the professionalism of teachers in teaching, can foster academic culture and quality among teachers or teachers. Learning outcomes can be seen from the increasing learning outcomes of students, both academics as set out informative tests, sub-summative tests, and end of the semester or summative tests. While those who are non-academic can provide attention, interest, motivation, and so forth, 2) Increasing the quality of learning, this is an inservice training tool, for teachers with new skills and methods, 3) can sharpen their analytical power and enhance teacher's self-awareness and students. 5) As a tool to incorporate additional approaches or innovations to sustainable learning systems that usually inhibit innovation and change. 6) To improve the quality of education and management of education efficiently by improving learning practices by developing skills so that students' motivation, interest and learning increase.

\section{CONCLUSION}

Based on the results of research that has been carried out starting from pre-cycle to cycle 2 in Social Science lessons, it can be concluded as follows: 1) In pre-cycle learning with KKM 75 obtained an average grade of 59 . Students who complete in learning the only amount to 6 people $(21 \%)$ and as many as 22 people $(79 \%)$ out of all 28 students. With the details of 14 male students and 14 female students. In cycle 1 learning, only 11 students (39\%) had complete learning and 17 people (61\%) were incomplete. Cycle 2 has completed 27 people (96\%) and incomplete 1 person (4\%). 2) The use of methods makes participants have the activeness, motivation, and interests of students for the better. All students participate actively 
in the game. Each group cooperates and competes to complete the task well thereby increasing the learning outcomes of students.

Based on the above conclusions several things should be done by teachers to improve student learning outcomes, among others, as follows: 1) Teachers should use varied and interesting teaching methods, 2) Teachers should use attractive learning media so that students can be helped in understanding learning, 3) Teachers should make improvements to learning through classroom action research so that they can contribute and provide benefits for the improvement of the learning process.

\section{REFERENCES}

Aliputri, D. H. (2018). Penerapan Model Pembelajaran Kooperatif Tipe Make A Match Berbantuan Kartu Bergambar Untuk Meningkatkan Hasil Belajar Siswa. Jurnal Bidang Pendidikan Dasar, 2(1A), 70-77. https://doi.org/10.21067/jbpd.v2i1a.2351

Anggraini, D. (2018). Pengembangan Alat Permainan Edukatif Dengan Barang Bekas Untuk Mengembangkan Bahasa Anak Usia Dini Di Ra Al-Hidayah Kecamatan Kasui Kabupaten Waykanan [Universitas Negeri Raden Intan]. http://repository.radenintan.ac.id/5219/1/skripsi lengkap.pdf

Anitah, S. W. (2014). Strategi Pembelajaran. In Strategi Pembelajaran di SD (Edisi kell, pp. 1-30). Universitas Terbuka. http://repository.ut.ac.id/3833/2/PBIS4301-M1.pdf

Arsyad, A., Sulfemi, W. B., \& Fajartriani, T. (2020). Penguatan Motivasi Shalat dan Karakter Peserta Didik Melalui Pendekatan Pembelajaran Kontekstual Pada Mata Pelajaran Pendidikan Agama Islam. Potensia: Jurnal Pendidikan Islam, 6(2), 185-204. https://doi.org/http://dx.doi.org/10.24014/potensia.v6i2.9662

Azizah, M. I. (2016). Efektivitas Pembelajaran Menggunakan Permainan Tradisional Terhadap Motivasi dan Hasil Belajar Materi Gaya di Kelas IV Min Ngronggot Nganjuk. Dinamika Penelitian, 16(2), 279-308. https://doi.org/https://doi.org/10.21274/dinamika.2016.16.2.279-308

Damanhuri, D., Hakim, Z. R., \& Pratiwi, M. U. (2016). Penerapan Model Pembelajaran Inquiri Terhadap Hasil Belajar Siswa Sekolah Dasar Pada Mata Pelajaran Ips. Jurnal Pendidikan Sekolah Dasar, 2(2), 156-167. https://doi.org/http://dx.doi.org/10.30870/jpsd.v2i2.796

Daryanto, D. (2014). Penelitian tindakan kelas dan penelitian tindakan sekolab: beserta contoh contohnya (Ed. 1; Cet, Issue 1). Gava Media. http://library.fis.uny.ac.id/opac/index.php?p=show_detail\&id=5915

Ginnis, P. (2008). Trik dan Taktik Mengajar: Strategi Meningkatkan Pencapaian Pengajaran di Kelas. In W. Dewanto (Ed.), Indeks (Cet.Ke-2). Indeks. http:/ /library.fip.uny.ac.id/opac/index.php?p=show_detail\&id=4378

Heryadi, T., Sulfemi, W. B., \& Retnowati, S. (2020). Pengembangan Metode Modeling The Way Berbantu Media Papan Tempel Dalam Pembelajaran Bahasa Indonesia. Jurnal Lingko, 2(2), 238-253. https://doi.org/https://doi.org/10.26499/jl.v2i2.63 
Komang Gunadi. (2012). Pengaruh Penerapan Model Pembelajaran Kooperatif dengan Teknik Tutor Sebaya Berbantuan Picture And Picture terhadap Hasil Belajar Tik Siswa Kelas VII Semester Ganjil SMP Negeri 1 Sukasada. Karmapati, 1(3), 376-387. https://doi.org/http://dx.doi.org/10.23887/karmapati.v1i3.19523

Miaz, Y. (2015). Penelitian tindakan kelas bagi guru dan dosen. In Penelitian tindakan kelas bagi guru dan dosen (jilid 1). Penerbit UNP Press Padang. http:// repository.unp.ac.id/71/

Mujinem, M., \& Kawuryan, S. P. (2013). Efektivitas Metode Permainan Dalam Pendidikan Nilai Danketerampilan Sosial Dalam Pembelajaran Ips Sekolah Dasar. Jurnal Penelitian Ilmu Pendidikan UNY, 6(2), 123566. https://doi.org/10.21831/jpipfip.v6i2.4792

Nikmah, S., Kartono, \& Halidjah, S. (2013). Penggunaan Metode Permainan dalam Pembelajaran IPA untuk Meningkatkan Aktivitas dan Hasil Belajar Siswa Kelas IV Sekolah Dasar Negeri 11 Sungai Melayu Rayak. Jurnal Pendidikan Dan Pembelajaran Khatulistiwa, 2(3), 57-77. https://jurnal.untan.ac.id/index.php/jpdpb/article/view/1207

Putri, H. P. (2018). Penerapan Metode Hypnoteaching Untuk Meningkatkan Kemampuan Menulis Puisi Anak Pada Siswa Kelas III SDN 030 Bagan Jaya. Jurnal Basicedu, 2(1), 148153. https://doi.org/https://doi.org/10.31004/basicedu.v2i1.133

Sediasih, S. (2017). Meningkatkan Hasil Belajar Siswa dengan Menggunakan Model Make A Match Pada Mata Pelajaran PKN di Kelas V SDN Karya Wangi 2. Jurnal Pendidikan Sekolah Dasar, 3(1), 74-81. https://doi.org/http://dx.doi.org/10.30870/jpsd.v3i1.1331

Sukmanasa, E., Windiyani, T., \& Novita, L. (2017). Pengembangan Media Pembelajaran Komik Digital Pada Mata Pelajaran Ilmu Pengetahuan Sosial Bagi Siswa Kelas V Sekolah Dasar Di Kota Bogor. Jurnal Pendidikan Sekolah Dasar, 3(2), 171. https://doi.org/10.30870/jpsd.v3i2.2138

Sulfemi, W. B. (2019). Model Pembelajaran Kooperatif Mind Mapping Berbantu Audio Visual Dalam Meningkatkan Minat, Motivasi Dan Hasil Belajar Ips. Jurnal PIPSI (Jurnal Pendidikan IPS Indonesia), 4(1), 13. https://doi.org/10.26737/jpipsi.v4i1.1204

Sulfemi, W. B. (2020). Pengaruh Rasa Percaya Diri Dan Gaya Kepemimpinan Kepala Sekolah Terhadap Kinerja Guru. Nidhomul Haq : Jurnal Manajemen Pendidikan Islam, 5(2), 157-179. https://doi.org/10.31538/ndh.v5i2.557

Sulfemi, W. B., \& Kamalia, Y. (2020). Jigsaw Cooperative Learning Model Using Audiovisual Media To Improve Learning Outcomes. Jurnal Pendidikan Sekolah Dasar, 6(1), 30-42. https://doi.org/http://dx.doi.org/10.30870/jpsd.v6i1.4919.g5063

Sulfemi, W. B., \& Mayasari, N. (2019). The Use of Audio Visual Media in Value Clarification Technique to Improve Student Learning Outcomes in Social Studies. Jurnal Pendidikan, 20(1), 53-68. https://doi.org/https://doi.org/10.33830/jp.v20i1.235.2019

Sulfemi, W. B., \& Minati, H. (2018). Meningkatkan Hasil Belajar Peserta Didik Kelas 3 Sd Menggunakan Model Picture and Picture Dan Media Gambar Seri. Jurnal Pendidikan Sekolah Dasar, 4(2), 228. https:/ /doi.org/10.30870/jpsd.v4i2.3857

Sulfemi, W. B., \& Setianingsih. (2018). Penggunaan Tames Games Tournament (Tgt) Dengan Media Kartu Dalam Meningkatkan Hasil Belajar. Journal of Komodo Science Education, 01(01), 1-14. http:ejournal.stkipsantupaulus.ac.id/index.php/jkse 
Sulfemi, W. B., \& Yuliana, D. (2019). Penerapan Model Pembelajaran Discovery Learning Meningkatkan Motivasi dan Hasil Belajar Pendidikan Kewarganegaraan 1. Jurnal Rontal Keilmuan PKn, 5(1), 17-30. https://doi.org/http://dx.doi.org/10.29100/jr.v5i1.1021

Sulfemi, W. B., Siswanto, S., Heryadi, T., \& Soleh, A. N. (2020). Model Project Based Learning Berbantu Media Kartu Dalam Pembelajaran Bahasa Indonesia Materi Kalimat Efektif Pada Surat Undangan. Jurnal Metalingua, 18(2), 271-284. https://doi.org/http://dx.doi.org/10.26499/metalingua.v18i2.612

Sutedi, D. (2016). Contrastive Analysis of Japanese and Indonesian Passive Sentences. Mediterranean Journal of Social Sciences, 7(1), 317-326. https://doi.org/10.5901/mjss.2016.v7n1s1p317

Wartik, W. (2017). Peningkatan Kemampuan Menulis Pantun Melalui Pendekatan Pembelajaran Contextual Teaching And Learning (CTL) Siswa Kelas IV Sekolah Dasar Negeri 24 Air Saleh. PEMB AHSI Jurnal Pembelajaran Bahasa Dan Sastra Indonesia, 7(1), 8597. https://doi.org/http://dx.doi.org/10.31851/pembahsi.v7i2.1362

Windiyani, T., Novia, L., \& Permatasari, A. (2018). Penggunaan media pembelajaran gambar fotografi pada mata pelajaran ilmu pengetahuan sosial siswa sekolah dasar. Jpsd, 4(1), 91101. https://doi.org/http://dx.doi.org/10.30870/jpsd.v4i1.2776

Yuliana, R., Cahyani, I., \& Sastromiharjo, A. (2015). Penerapan Strategi Partisipatif Melalui Media Gambar Denah dan Kartu Pancing Foto Dalam Pembelajaran Pemahaman Konsep Dan Berbicara Siswa Sekolah Dasar. Jurnal Pendidikan Sekolah Dasar, 1(2), 1-12. https://doi.org/http://dx.doi.org/10.30870/jpsd.v1i2.699 